\title{
THE LEGACY OF DIFFICULTY IN THE RUSSIAN POETIC TRADITION: CONTEMPORARY CRITICAL RESPONSES TO IVANOV's COR ARDENS
}

\begin{abstract}
"Ky - samyi neponiatnyi, samyi temnyi, $v$ obydennom slovoupotreblenii, poet nashego vremeni - imenno ottogo chto kak nikto verny svoei stikhii - soznatel'no poruchiv sebia ei."

Mandel'shtam to Ivanov, $1909^{1}$

"Viacheslav Ivanov bolee naroden $i v$ budushchem bolee dostupen, chem vse drugie russkie simvolisty. [...] Oshchushchenie proshlogo kak budushchego rodnit ego $s$ Khlebnikovym."
\end{abstract}

Mandel'shtam, $1923^{2}$

For various reasons, Ivanov scholarship since the 1920's has tended to concentrate primarily on his role as a religious thinker, or on his contributions to literary and cultural history. ${ }^{3}$ This may well be a reflection of this century's preoccupation with the fate of humanist values, and more recently with models of cultural history and critical theory. The result, however, has been a certain obscuring of the image of Ivanov the poet. One could almost argue that, in a sense, the line of continuous and direct response to his poetry has been broken off and not fully restored since the time of the revolution.

For this reason it is of considerable interest to return today to the contemporary responses articulated by Ivanov's fellow-poets, and to take a fresh look at them as a basis for assessing Ivanov's place within the Russian poetic tradition. Cor Ardens has been selected as a representative and comprehensive example of the poet's art at 
a mature stage of his development. Reviews of this collection were written by Briusov, Kuzmin, Chulkov, Khodasevich, Gumilev and Gorodetskii. These are a particularly valuable source as they reflect the reactions of poets rather than of critics, and provide an insight into the contemporary reading of Ivanov's verse.

In considering these responses, this paper will focus on one issue in particular, that of contemporary attitudes to the difficulty of Ivanov's poetry. This concept is central both to Ivanov's verse and to his poetics; it provoked wide-ranging debate among his contemporaries but has received little serious attention in ensuing years. Although almost all writing on Ivanov includes an obligatory passing reference to his alleged difficulty, the nature of this difficulty and its implications for the poet's legacy to future generations have never been discussed in any detail.

The paper falls into three parts. The first discusses the concept of difficulty in poetry, considered in relation to the development of the Russian poetic tradition and to Ivanov's place within this tradition. The central and most extensive part of the paper analyses the responses to this issue reflected in the six reviews of Cor Ardens under consideration. The final section considers the question of the subsequent legacy of Ivanov's verse with particular reference to its difficulty.

"Difficult poetry", that is to say poetry of which it is not easy to discern the meaning, can arise for two main reasons. The subject or theme being dealt with may in itself be very complex. Hence poetry with a marked philosophical orientation tends to be less accessible than purely lyrical verse on love or nature. Various formal aspects of the poem may also contribute to an overall sense of difficulty. Common symptoms of formal complexity are a proliferation of recondite allusions or references, the use of private and subjective imagery, an elliptical style, unusual or loose syntax, archaic, ornate or foreign language.

These two distinct aspects of difficulty - which could be termed "profundity of thought" and "obscurity of expression" - were both highly characteristic of Ivanov. Although they are often connected, they do not necessarily depend on each other. While difficulty of expression may well arise as a response to perceived complexity of theme, it can also be a purely formal device, a type of surface play or linguistic game. A complex subject may be expressed in simple form, just as a straightforward one may be dressed up in allusive, difficult language.

Poetry is generally deemed to be difficult when there is a gap between the poet's practice and the expectations or knowledge of the reader. Since expectations are largely conditioned by habit, and knowledge is developed through familiarity, it is evident that difficulty in poetry is a relative concept subject to shifting perceptions as the generations succeed each other and poetic practice evolves. In cases where the general readership lags behind the poet, the critic's function has often been to help the reader bridge this gap by educating and refining his perceptions. With hindsight, difficulty as a category can often be seen to have played a pioneering and innovative role, as Tynianov demonstrated in Arkhaisty $i$ novatory. These considerations apply very clearly to the case of Ivanov. 
When the question of difficulty in poetry is considered from a historical perspective, one can see that there were various periods in which this tendency was particularly marked. Outside the Russian tradition, one could point to several examples: the Alexandrian poets in Ancient Greece, Dante in medieval Europe (his treatise on poetry, De vulgari eloquentia, provided one of the earliest "modern" definitions of the appropriateness of a "difficult" style in poetry), ${ }^{4}$ the English metaphysical poets of the seventeenth century, or, in the German tradition, philosophically and mystically inclined poets such as Schiller, Goethe or Hölderlin. ${ }^{5}$

Ivanov, as we know, drew on most of these traditions - perhaps the only visible exception is that of the English metaphysical poets. ${ }^{6}$ What of his native tradition, however? What models of difficulty did it provide, and how did he relate to these? This question was of particular concern to Ivanov's readers and critics in their attempts to locate him within the Russian tradition.

In Russian poetry, the tradition of difficulty based on esoteric content goes back to early translations, variations and commentaries based on the Bible and Psalms, the root - as in European literature, of the whole concept of sacred meaning giving rise to a symbolic form of expression which requires decoding through interpretation and commentary. There is, however, an important difference. Whereas the original Hebrew language of the Bible and Psalms is a remarkably simple and transparent medium, in translation it has undergone a process of "obscuration" - particularly in the case of its Church Slavonic and Russian versions. This has led to a much greater nationally inherited tradition of the sense of the "difficulty" of a sacred text - a consciousness which has in turn had an important philological bearing on Russian poetry.

In Ivanov's case, the early formative experience of reading the Psalms with his mother evidently developed in him the sense of difficulty of expression as an intrinsic characteristic of sacred meaning, linked to an awareness of his own poetic vocation; ${ }^{7}$ this then became an integral part of his poetics, even leading him to incorporate difficulty into the texts of other writers through translation. ${ }^{8}$

The beginnings of secular poetry in the eighteenth century were closely associated with "difficulty", based in part on the imitation of biblical and classical models, and also linked to the use of Church Slavonic; this linguistic aspect of difficulty was first formulated and enshrined as a theoretical principle by Lomonosov. ${ }^{9}$

In the mid-1820's the poets of the "Liubomudry"circle attempted to introduce a new type of self-consciously philosophical poetry which would reflect their interest in German idealism and transcendental metaphysics. Although their views met with a certain response, the "norm" of literary practice nevertheless remained the values of simplicity, clarity and smoothness in poetry embodied by Pushkin, and only occasionally challenged by poets often not fully recognized in their day such as Baratynskii or Tiutchev. ${ }^{10}$

With Tiutchev and later Vladimir Solov'ev Russian literature saw a return to verse with an explicit philosophical and religious content (hence the frequent use of the term "poet-myslitel"by Vladimir Solov'ev). It is important, however, to underline that depth of content in the works of these poets was not in general paralleled by an accompanying complexity of form - Tiutchev's message seems to be that depth of thought ultimately lies beyond, and eludes expression through language, while Solov'ev resorted to a mildly ironic style in several of his mystical 
poems. Although the language of their poetry is often abstract, it is not particularly difficult, either in terms of syntax or in terms of allusions.

By the time Ivanov appeared on the literary scene, one could therefore argue that whereas profundity of thought in poetry had carved out a certain niche for itself, its formal correlative - complexity of allusion, syntax and language - was not yet a common part of current literary practice. Against this background, one can appreciate the unconventionality of Ivanov who, from the very outset of his poetic career, adopted a deliberately "high" style of poetic diction which was "difficult" both in terms of its content and its form. In a sense, as Averintsev has aptly commented, Ivanov was attempting to return poetry to its pre-Pushkinian sources. ${ }^{11}$

The title and opening poem of his first book, Kormchie zvezdy, established his intention to concern himself in his poetry with metaphysical and philosophical issues - aligning himself within the tradition of Tiutchev, Dostoevskii and Solov'ev. On the formal level, several aspects of his poetics placed particular emphasis on the value of difficulty. The view that poetry and culture are a form of memory gave rise to the practice of a wide range of classical and biblical allusions, while the belief that the root of all symbols lies deeply buried in myth led to a deliberate cult of obscurity and veiled speech. Following the example of sacred and liturgical texts, obscurity was also regarded as a deliberate method for initiating the reader into the secrets of mystical experience.

Readers and critics were quite unprepared for the difficulty of Ivanov's themes as well as of their expression, and had little grasp of the underlying concepts. When Kormchie zvezdy appeared, all the reviewers remarked on its difficulty. Right from the beginning, two lines of response were demarcated - by far the most common being the negative one.

The battle over the right of poetry to concern itself with abstract, philosophical or religious issues, to be objective in tone rather than overtly personal, was clearly not yet won, despite the precedents set by Tiutchev and Solov'ev. ${ }^{12}$ One of the unspoken premises behind most of the early reviews of Ivanov's poetry is that verse must have some personal, emotional content. Ivanov's preoccupation with universal issues was seen by many as evidence of an arid intellectuality.

In the area of form, critics strove to outdo each other in levelling accusations of difficulty and unreadability at Ivanov's verse. Here again there was an unspoken assumption that poetry should be easily accessible and that intellectual effort precludes enjoyment. It was dimly recognized that Ivanov was trying to revive an aspect of Russian poetry which had largely been lost since the eighteenth century, but the stock comparisons of Ivanov to writers of this period were invariably derogatory and served to portray him as an anachronistic relic from the past. ${ }^{13}$ Critics failed to relate the formal difficulty of his poetry either to his subject matter or to his poetics. They persisted in regarding it as wilful obfuscation, as a symptom of confused thought or as evidence of scholastic pedantry; Ivanov was frequently dubbed a scholar masquerading as poet but unable to shed his academic bookishness. ${ }^{14}$ This attitude led to several merciless reviews and parodies in which Ivanov was often caricatured as a born-again Tred'iakovskii. ${ }^{15}$

The positive response was much less common. In the main it was advanced by poets rather than critics, by Briusov for example, who defended the right of poetry to concern itself with transcendent matters from an early date, and regarded Ivanov's complexity of form as the natural and adequate expression of his ideas, or by Blok 
who promoted obscurity in the light of Ivanov's own view of the development of symbolist art. ${ }^{16}$

\section{II}

By the time the first volume of Cor Ardens appeared in 1911, there was therefore quite a firmly built up legacy of negative opinion about Ivanov's verse, all focused on the issue of its difficulty, and only partly offset by a small minority of dissenting voices.

The balance had however shifted in one significant respect. Ivanov's position in Russian literature was no longer that of an outsider but was now that of an established leader and recognized poet. If the earlier critics had seen their role as consisting in either permitting or not permitting the intrusion of this new type of poetry onto the literary scene, seven or eight years later this was no longer the issue - the poetry was established de facto. Furthermore, symbolism as a movement was beginning to lose support from within its own camp, and was being challenged from without by new emergent literary groupings. The main thrust of the discussion at this point therefore changed from whether to allow difficulty to whether to view this difficulty as productive, whether it was relevant to contemporary readers and whether it showed a path forward for the next generation.

In considering the reviews of Cor Ardens written by Ivanov's contemporaries, we shall start with those written by established "senior" poets such as Briusov (18731924) and Kuzmin (1872-1936), moving on through Chulkov (1879-1939) to three younger poets of the next generation, Gumilev (1886-1921), Gorodetskii (18841967) and Khodasevich (1886-1939). In each case the focus will be on the particular poet's response to Ivanov's difficulty - on his understanding of its sources and function, and on his view of its role in relation to the future development of Russian poetry.

Valerii Briusov was the earliest and most regular reviewer of Ivanov's collections of poetry. ${ }^{17}$ From the very outset, he singled out the issue of difficulty and evolved a positive response to it, based on a number of considerations. He fully accepted that abstract ideas and religious themes could form the subject of poetry, and regarded difficulty of form as the necessary and appropriate correlative of complexity of content. He strongly welcomed the poet's technical innovations, particularly in the area of versification, and found his new ideas and formal experiments very much in tune with contemporary needs. The poet's difficulty was acknowledged, but linked to his innovations and viewed as an inspiring and rewarding challenge to the reader. ${ }^{18}$

If at first Briusov's comments on Ivanov's difficulty were tinged with a certain amount of reservation, by the time he came to reviewing Cor Ardens the critical note had almost entirely disappeared. ${ }^{19}$ The reviews which he wrote of each part of Cor Ardens appeared in Russkaia mysl' in 1911 and 1912 and were both extremely flattering, particularly the second one. ${ }^{20}$ This consistent rise in praise is all the 
more remarkable when one recalls that throughout the late 1900 's the fundamental differences between Ivanov's and Briusov's aesthetic positions became increasingly apparent, culminating in their heated polemical exchange of 1910 on the pages of Apollon. ${ }^{21}$

In his review of the first volume, although he continues to express a few reservations over occasional excesses of form, Briusov perceptively detects a general tendency towards greater simplicity of syntax and language (this was indeed the case as Ivanov's next collection, Nezhnaia taina, revealed). Furthermore, in assessing the question of Ivanov's relevance to the present, he makes the point that the poet's absorption in classical sources, far from distancing him from the concerns of the present, gives his voice an unusual and rare strength.

The second review was written as part of a longer article surveying over fifty recent books of poetry published in 1911 and 1912. Out of all these, Briusov singles out the second part of Cor Ardens as an "outstanding phenomenon in contemporary literature", and awards it first place as the only truly valuable book to have appeared in recent years - high praise indeed when one considers the competition.22 The review is studded with phrases such as "polnaia prosvetlennost", "produmannost' mysli","kniga istinnogo poeta $i$ istinnoi poezii", Briusov praises Ivanov's perfect mastery of verse, his highly individual lexicon and syntax and, while recognizing that these may cause difficulty to certain readers, takes the view that the poet's elevated style entirely corresponds to the ideas expressed.

However, on the question of how this difficulty related to the current scene, of whether Ivanov showed a path forward, Briusov is a little bit equivocal. On the one hand, he underlines Ivanov's key role as an "uchitel" several times. And yet he states that Ivanov is not a poet for the present day (the title of his review was "Segodniashnii den' russkoi poezii"), not only because he is a poet of the previous generation, but also because his verse stands "outside time" ("vne vremeni"). He writes that the reader can easily forget that Ivanov is a contemporary because his verse addresses itself to universal issues. Briusov does not seem to mean this negatively - he is simply pointing out that Ivanov's themes are not topical but eternal.

Concluding his review of the works of poets of the older generation, Briusov commented that Ivanov's standing is unique - among the poets of the older generation, only he has played the role of " $u c^{\prime}$ hitel", and only his verse has brought new revelations and marked a fresh stage in the conquest of new areas in art:

"Sredi nikh, tol'ko Viach. Ivanov vystupil kak uchitel'. V knigakh drugikh est' khoroshie stikhi, u odnikh bol'she, u drugikh men'she, no novogo otkroveniia oni nam ne prinesli. Ikh stikhi - eto literatura, pokazyvaiushchaia sravnitel'no vysokii uroven' obshchei nashei dukhovnoi kul'tury, no ne etapy na puti zavoevaniia novykh oblastei iskusstva."

Here Briusov is at his most perceptive in his understanding that it was through his innovations that Ivanov achieved his status of teacher and assured his legacy to future generations - particularly, one might add, through his novel use of "difficulty" in poetry. ${ }^{23}$

Although Mikhail Kuzmin was among Ivanov's more senior contemporaries and lived for several years in the bashnia, he did not publish any reviews of Ivanov's 
earlier works. He did, however, compose a very thoughtful and considered review of the first part of Cor Ardens. Its publication (in truncated form) in the 1912 opening issue of Trudy $i$ dni alongside two essays by Ivanov in defense of symbolism ("Mysli o simvolizme" and "Orfei") set the collection and its appraisal firmly within the context of the symbolist revival advocated by the journal. ${ }^{24}$

Whereas Briusov's response to Ivanov's difficulty was mainly on the formal level (to the surface evidence of this difficulty as it manifested itself through language and syntax), Kuzmin delved rather deeper. Out of all the reviewers of Cor Ardens, he perhaps comes closest to confronting the issue of difficulty, not simply stating the phenomenon, but attempting to uncover its underlying well-springs. This is particularly interesting in view of Kuzmin's role as the promulgator of "prekrasnaia iasnost" in 1910, and his mid-way stance between the older generation of Symbolists and the emergent generation of Acmeists. ${ }^{25}$

He singles out two factors contributing to Ivanov's difficulty, and defines both. Ivanov's underlying line of thought is not spelled out explicitly, but is expressed elliptically through a surface sequence of images; this requires a special imaginative effort on the part of the reader, referred to by Kuzmin as the capacity to think through images ("obrazno-myslitel'naia sposobnost"). Furthermore, the intensity of the thought expressed leads to a rich compression of the poetry ("nasyshchennost"), another factor which increases its "difficulty".

Kuzmin therefore concludes that whereas Ivanov's poetry is clearly not designed for the lady of leisure who wishes to sigh over a volume of light poetry after returning from an evening out, it is poetry for the serious reader who is prepared to rise to the challenge and who will derive much pleasure from the effort invested. ${ }^{26}$

There is an important implication here that Ivanov's poetry has played a special innovative role by creating a new type of reader. In his review Kuzmin has effectively pinpointed the two aspects of Ivanov's "difficulty" as a poet which contributed directly to post-Symbolist and particularly to Acmeist poetics - the tendency to express ideas directly through images, and the resulting very dense compression of the text. These aspects of Ivanov's poetics placed new requirements upon the reader, thereby preparing the way for the Acmeist poetry of the next generation.

Kuzmin goes even further and argues that the common accusation of incomprehensibility levelled at Ivanov's poetry merely reflects the limitations of a lazy readership, unable to discern the simplicity and even transparency which lies beyond the surface difficulty of Ivanov's lyric verse:

“...lenivomu chitateliu simulirovat' neponiatlivost' ochen' udobno, my zhe utverzhdaem, chto 'slova' Viach. Ivanova vsegda poniatny $i v$ p'esakh chisto liricheskikh [...] dostigaiut vysshei prostoty (no ne pustoty) $i$ prozrachnosti."27

Georgii Chulkov is one of the few reviewers of Cor Ardens, perhaps the only one, who does not explicitly address the issue of Ivanov's difficulty as a poet - however, a recognition of the problems posed by this issue seems to underlie the emphasis he places throughout his review on the relevance of Ivanov's verse to the contemporary reader. 
His review of the first part of Cor Ardens appeared in Apollon ${ }^{28}$ and opens with a highly suggestive and extended architectural metaphor - the book is compared to the ancient church of San Clemente in Rome. This church, like many, was built up in several layers over a pagan foundation. ${ }^{29}$ In its underground section it contains a fresco of the Madonna, depicted, according to Chulkov, with wild Vrublev-like eyes, which liken her appearance to a Maenad and make her look very contemporary.

The point of this comparison is two-fold. On the one hand, it serves as an image of Ivanov's historicism and of the eclectic nature of his inspiration - most specifically it highlights the close structural interdependence of classical and Christian motifs in his poetry. On the other hand, through his description of the Maenad-like Madonna, Chulkov brings out the way in which Ivanov was able to forge a link between past and present by seeking out those esoteric aspects of pagan antiquity and Christian mysticism which were most in tune with the contemporary mind.

The other area in which Chulkov finds that Ivanov speaks directly to the modern reader is through his association of the microcosm or private world of personal experience with the macrocosm of universal truths, a type of symbolism which Chulkov, following Ivanov's own terminology, terms realism. ${ }^{30}$ In this respect Chulkov regarded Ivanov as an exceptional phenomenon in contemporary poetry (which in his view was becoming either purely lyrical or drily intellectual in character).

These two areas - Ivanov's transcendent or symbolic realism and his dense web of historical mythological allusion are those aspects of his poetry which are usually most closely associated with his difficulty. Although Chulkov does not discuss this issue directly, the whole thrust of his review seems to be the desire to make plain the vital relevance of these concerns to the modern age, despite their apparent difficulty or abstruseness. This point is further strengthened by the examples from Cor Ardens which he has chosen to illustrate his review - the highly topical cycle about the events of 1905, "Godina gneva" and the soul's embrace of the dark night of erotic love in the third book, "Eros".

Chulkov's deliberate emphasis on Ivanov's relevance to contemporary preoccupations was no doubt intended to counter a growing tendency to deny Ivanov a place in the future of Russian poetry on the grounds of his difficulty and ornate complexity. It may well have been partly directed against Gumilev whose review of the first part of Cor Ardens (published just a few months earlier in the same journal) initiated this tendency. ${ }^{31}$

Nikolai Gumilev's two reviews of Cor Ardens mark the beginning of the move towards a new type of negative reading of Ivanov's difficulty. The reviews were written in the key years during which Gumilev was establishing his own Acmeist platform. Both appeared on the pages of Apollon, separated by an interval of one year; not surprisingly, there is a strong progression from the first to the second, reflecting the intensification of the current polemical debate between symbolism and acmeism. $^{32}$

In the first review, Gumilev recognizes both the intensity of Ivanov's thought (he writes of his "napriazhennoe myshlenie", and the resulting complexity of form, particularly of language; he also acknowledges the interdependence of these two levels of difficulty. 
Reading more closely, however, one can already discern the beginning of his attempts to disengage himself from Ivanov's powerful ideological influence. He achieves this through a subtle use of language and inference. One of his principal devices is the use of the word "prizrachnost" to characterize Ivanov's images, substituted for the poet's own term "prozrachnost". The latter was well-known as a key concept of Ivanov's metaphysics and poetics - transparency testified to the objective truth of the relationship between signs and the signified, between symbols and transcendent truth in the real world as well as in art. Gumilev - who was well aware of the full significance of Ivanov's term and had in fact used a form of it (the word "prozren'e") in an epigraph from Ivanov appended to his earlier collection of verse $^{33}$ - deliberately changes it into "prizrachnost ${ }^{\text {" }}$ thereby clouding the original transparency and, more importantly, depriving the relationship of its ontological basis. Similarly, although he pays tribute to the poet's amazingly rich and varied language, he simultaneously devalues it by characterizing it as the language of a philologist rather than of an inspired poet.

The negative connotations of Ivanov's complexity of thought and difficult language which are just hinted at in the first review are much more fully developed a year later in the second review. Here Gumilev uses terms like "ukhishchrennost" and "vitievatost" for Ivanov's language and writes of his syntax as "painstakingly obscuring the general sense of the sentence" ("tshchatel'no zatmevaiushchei obshchii smysl frazy") [P.D. emphasis]. A three-stage transition has taken place from the clarity of Ivanov's original pure "prozrachnost" through an intermediary, uncertain limbo of "prizrachnost" into the final confusion of " $t$ ' $m a$ ". ${ }^{34}$

Having thus effectively shifted Ivanov's verse from the realm of transparency into that of shadowy darkness or obscurity, Gumilev then makes a direct transition to the issue of future paths which may lead on from Ivanov; he concludes that following the poet along his path would be a perilous, even fatal adventure, for Ivanov represents an extreme of the Slavonic soul to which one must say "net", "serdtse Rossii prostaia Moskva, a ne velikolepnyi Samarkand" [P.D. emphasis]. The opposition between the words "prostaia" and "velikolepnyi" is significant. It reveals that Gumilev achieved his polemical objective of marginalising Ivanov writing him out of the future history of Russian poetry - on the specific grounds of simplicity versus ornate complexity - difficulty of ideas and of their expression in language, viewed as a dead end in Russian poetry.

In the following year, in a short review of Nezhnaia taina, the collection which marked Ivanov's turn towards a much simpler style of poetic diction, Gumilev praised the poet's new-found "iasnost' $i$ prekrasnaia prostota"; however, he still reiterated his claim, established on earlier grounds, that Ivanov's path had diverged irreconcilably from the future development of contemporary poetry. ${ }^{35}$

Sergei Gorodetskii's brief review of Cor Ardens was published in the opening issue of the new Acmeist journal Giperborei, and printed alongside his review of Gumilev's Chuzhoe nebo. ${ }^{36}$ This juxtaposition is significant, and reinforces the message implied in Gorodetskii's opening editorial note - that Ivanov's name belongs to the past of Russian poetry, while Gumilev belongs to its future. ${ }^{37}$

In tune with this general approach, Gorodetskii's review of Cor Ardens is duly deferential to Ivanov, but nevertheless somewhat reticent in tone. It pays respect to 
Ivanov as an original theoretician and influential "uchitel", but depicts him more as a historical representative of symbolism than as a living poet for the present. This reading is supported by a key sentence which was included in the original draft review but removed from the published version: "[Cor Ardens] otrazhaet nachalo, apogei $i$ uklon togo poeticheskogo mirosozertsaniia, kotoroe stroit na pochve simvolizma Viach. Ivanov." 38

Gorodetskii comments that the second part of Cor Ardens "vpadaet v simvoliku, skoree srednevekovuiu, chem sovremennuiu" - thereby suggesting that a preoccupation with past cultures somehow precludes contemporary relevance (exactly the attitude which Chulkov had tried to counter in his earlier review). He then continues to link this point with the difficulty of Ivanov's language: "sklonnyi $k$ slavianizmam, printsipial'no tiazhelyi, iazyk knigi ne vsegda prekrasen $i$ chasto ne lishen temnot" [P.D. emphasis]. He also remarks that the tone of the book is too static ("nedostatochno podvizhen") and thereby induces a sense of fatigue in the reader.

This is in marked contrast to the stance which Gorodetskii had taken only a few years earlier in an essay of 1909 which included some discussion of Ivanov's Eros. Here he praised the collection for its exciting experimental use of language, regarded as the embodiment of the energetic principle ("printsip energetizma"), and defended the poet's mixed use of classical and Slavonic images, interpreting this in the context of a national renaissance as a means of revealing the universal elements latent in the poet's native culture. ${ }^{39}$

Following the trend set by Gumilev, in his review of Cor Ardens Gorodetskii used the difficulty of Ivanov's verse for polemical purposes as a means of casting a shadow over the achievement of the older poet and paving the way for the new poetry of the younger generation. This point is further underlined by Gorodetskii's comments on Gumilev's Chuzhoe nebo which immediately follow his review of Ivanov. Here Gumilev's verse is praised for precisely those features which set it apart from the poetry of symbolism and of his earlier mentor, Ivanov. Particular emphasis is placed on Gumilev's simplicity, and on his struggle with two forms of difficulty philosophical and verbal:

" $V$ nem chuvstvuetsia bor'ba s peregruzhennost'iu poezii s odnoi storony filosofskim ballastom, a s drugoi - slovesnym liro-magicheskim. Namerenno prostaia muza N.

Gumileva tem ne menee ne khochet dlia sebia kakikh-libo ogranichenii v vybore tem.[...] Chuzhdaias' vsiakikh debrei, ona preimushchestvenno skol'zit po periferii dukha, a ne ustremliaetsia $k$ ego tainikam. " [P.D. emphasis].

Here Gumilev's "deliberately simple Muse" is held up in contrast to another type of poetry, characterized by difficulty of content (a preoccupation with philosophical questions and with the mysteries of the spirit) and by a certain richness of form. The struggle against philosophical heaviness is most likely a reference to Ivanov while the attack on verbal lyrical magic may well also be aimed at him as well as at Blok.

These two reviews, when read in conjunction, seem to reinforce the message that Ivanov's poetry, because of its heaviness and difficulty, belongs to the past, and is giving way to a new poetry of greater simplicity epitomized by Gumilev.

A more explicitly comparative approach between the two generations is adopted by Vladislav Khodasevich; his comments on Cor Ardens and Nezhnaia taina occur 
in the context of a long review article of 1914 which considers the new work of young poets against the background of recent books published by poets of the previous generation. ${ }^{40}$ Written a few years later than the other reviews of Cor Ardens, and accordingly from a consciously retrospective point of view, the article deliberately seeks to address the question of the older poets' relevance to the next generation. From the poets of the older generation, Khodasevich selects only four, Ivanov, Briusov, Bal'mont and Baltrushaitis.

He does not write directly of Ivanov's complexity, but touches upon the subject obliquely by underlining the poet's extraordinary erudition and scholarly knowledge, and its impact on the wide range of allusions and images and themes dealt with in his verse. Like Chulkov, he elaborates an architectural metaphor for Cor Ardens - but the purpose of this comparison is somewhat different. Both writers liken the book to a church building in order to convey their sense of its overall unity and structure; both have also picked on buildings which reflect a great number of different cultural epochs to evoke the eclectic variety of its author's thought, images and language.

Here, however, the comparison ends. For whereas Chulkov presented the church of San Clemente in Rome as a harmonious image of Ivanov's pagan-Christian syncretism, underlining its special relevance to contemporary searchings, Khodasevich takes a different view. He chose San Marco in Venice as a supreme example of an eclectic richness in architecture and ornamentation which, while reflecting an impressive accumulation of past treasures, defies repetition or imitation and shows no path for the future. ${ }^{41}$ In a similar vein he sees Ivanov's collection as a vast treasure-house of past riches, providing a masterly retrospective summary, but yielding no forward path: “Tochno tak zhe, kak i San Marco, tvorchestvo Viacheslava Ivanova neizbezhno voidet $v$ istoriiu, no esli $i$ vyzovet naivnye podrazhaniia, to ne budet imet' prodolzhatelei." [P.D. emphasis].

Khodasevich's comparison reads brilliantly and persuasively, particularly as it is ingeniously developed out of the very terms used by Ivanov in his own poem on San Marco included in the last book of Cor Ardens. ${ }^{42}$ But whereas Ivanov had presented San Marco as an unfading image of the spiritual riches of art, Khodasevich uses it to write a form of closing epitaph upon the poet's work.

The negative reading of Ivanov's richness and erudition in terms of its fruitfulness for future generations follows the trend set by Gumilev's association of Ivanov with "velikolepnyi Samarkand" rather than with "prostaia Moskva". Although Khodasevich continues with a brief comment on Ivanov's complete mastery of poetic form, he does not make the point that this in itself can be a source of inspiration and innovation for future generations. It was only many years later, in 1936, as contemporary polemics receded and a broader more long-term perspective evolved, that he adjusted the emphasis of this assessment in Ivanov's favour, as shall be seen in the concluding section of this paper.

\section{III}

The above survey of contemporary responses to Cor Ardens has revealed a fairly wide variety of reactions to the generally acknowledged "difficulty" of the poet's verse. All the reviewers comment and agree on this aspect of Ivanov's poetry, but 
the "reading" of difficulty, the value attributed to it and the interpretation of its role in the future development of Russian poetry are far from uniform.

Whereas critics reviewing Cor Ardens for conservative periodicals such as Niva continued in the old manner to see Ivanov's erudition and difficult style as evidence of a dry pedanticism, incompatible with true poetic inspiration, ${ }^{43}$ contemporary poets were much more sympathetic and perceptive in their reading of this aspect of Ivanov's verse. On the whole, as we have seen, Ivanov's most ardent supporters were to be found among writers of the older generation, Briusov, Kuzmin and Chulkov. These writers were all quick to appraise his verse, and to recognize in its difficulty a source of innovation, a fresh challenge to the reader, or a contemporary modern message.

It was the younger generation of poets, Gumilev, Gorodetskii and Khodasevich, who introduced a less generous, more critical note into their assessment of this difficulty. ${ }^{44}$ Although they paid tribute to the technical achievements of Ivanov's verse, they tended to relegate him to the past and to cite the difficulty of his poetry as a factor which made him impossible to follow and which set him apart from the future development of Russian poetry.

It is tempting, with hindsight, to try and resolve these differences of opinion. What was, in fact, the legacy of Ivanov's "difficulty"? Was it just an exotic by-way or dead end in the Russian poetic tradition, or was it a source of forward impetus? This question can perhaps best be answered by drawing a distinction between two separate aspects of Ivanov's "difficulty", related to his twin roles as a teacher of verse and preacher of ideas.

In the first area Ivanov's legacy was tremendous. Even Gumilev - who wished to deny Ivanov his poetic posterity - wrote to Briusov that it was only after meeting Ivanov that he began to understand what poetry was all about. ${ }^{45}$ On the level of versification technique, language and syntax - Ivanov introduced a whole range of new possibilities, and thereby greatly extended the boundaries of Russian poetry. Some of the innovations may have been overdone or appeared clumsy at the time, but as Briusov pointed out, these were productive mistakes from which others could learn. ${ }^{46}$ In his eclectic use of imagery and of historical sources Ivanov introduced not only a whole new language of images and range of cultural references, but also a method of textual allusion which the next generation, particularly the Acmeists, absorbed and refined. Furthermore, as Kuzmin recognized in his sensitive review, he developed a way of thinking through images, the language of thought in poetry, which later poets were quick to build on and develop. These "difficult" aspects of Ivanov's poetry brought about a general change in sensibility - post-modernist readers accept and even welcome difficulty in poetry which no longer requires defending.

As far as Ivanov the preacher of ideas is concerned, here his impact was very great, but the channel of transmission was less direct. The complex system of religious aesthetics which Ivanov built up in his verse and prose writings acted as a sort of catalyst against which the younger generation could react. The monolithic all-embracing nature of the system, coupled with Ivanov's own magnetic personality as a teacher-figure all combined to create for the next generation a common point of departure - but this legacy was transmitted through the mechanism of resistance and even rebellion rather than through a smooth process of unchallenged assimilation. 
This point was recognized at the time by several of Ivanov's contemporaries. In 1909 Mandel'shtam wrote to Ivanov expressing profound admiration for his book of essays Po zvezdam but complaining that it was too "round" ("slishkom kruglaia") and impenetrable as a result. ${ }^{47}$ A few years later, in 1912, Blok shrewdly noted that Gumilev's response to Ivanov could only be understood in psychological terms "kak bunt protiv Viach. Ivanova $i$ dazhe kak zhelanie razviazat'sia s ego avtoritetom $i$ despotizmom."48 After the revolution, Tsvetaeva wrote a cycle of poems in 1920 addressed to Viacheslav Ivanov, conveying with retrospective insight the full complexity of an ambiguous relationship of longed for submission to the figure of a wise and aged " $u$ chitel" whose teachings had earlier been resisted and still partly eluded comprehension. ${ }^{49}$

Not surprisingly, Ivanov himself was also fully aware of his formative impact as a source of "negative" influence on younger poets, and even relished this role and openly cultivated it. In a report of the debate sparked off by Ivanov's and Belyi's 1912 lectures on symbolism, Nedobrovo drew attention to the anti-symbolist objections raised by Gumilev and Gorodetskii and concluded with the following perceptive comment:

“... glavnoe znachenie dokladov V.I. Ivanova i B.N. Bugaeva zakliuchaietsia $\mathrm{v}$ bolshoi ottalkivatel'noi ikh sile, vsledstvie kotoroi, oni, byt' mozhet, pomogut stoiashchei na ocheredi peregruppirovke poeticheskikh sil. [...].Nakonets, po povodu ottalkivatel'noi sily nekotorykh polozhenii, soderzhashchikhsia v dokladakh, V.I. Ivanov zaiavil, chto vvedenie etoi sily v ego mysli bylo proizvedeno prednamerenno. "50

The reviews considered in this article bear witness to the two-fold impact of Ivanov's innovatory role and legacy as a "difficult" poet - both directly, as Briusov and Kuzmin underline, but also indirectly, as a stimulus to reaction and selfdefinition, as we can see particularly clearly from the case of Gumilev.

In the same way as formalism took up some of the principles of symbolism and gave them a new lease of life in secularized form, the post-Symbolist poets assimilated certain features and techniques of Ivanov's verse while revoking its close association with the transcendent system of symbolist aesthetics. This tendency initially developed as a natural reaction against the teachings of the previous generation; later, however, in Soviet times, it solidified into a much cruder, politically motivated form, typified by Gorodetskii's assertion in 1925 that the current task of modern poetry was to divest symbolism of the poison of idealism and to rebuild it on a solid new foundation of materialism. ${ }^{51}$

It is instructive in this respect to compare the fates of Ivanov's attempted "revival of difficulty" linked in part to the traditions of the eighteenth century, and T.S. Eliot's slightly later rediscovery of the English metaphysical poets and attempt to reinstate them within the mainstream tradition of English poetry. Both poets' return to earlier sources as models of difficulty represented important potential sources of influence on the subsequent course of their native poetic traditions, but in the case of Ivanov, for historical reasons, the impact of this influence was diverted.

When T.S. Eliot wrote his key essay on the metaphysical poets in 1921, he concluded with words which may now be relevant to the question of the future of Ivanov's legacy as a "difficult" poet to the Russian tradition: 
"It is not a permanent necessity that poets should be interested in philosophy, or in any other subject. We can only say that it appears likely that poets in our civilisation, as it exists at present, must be difficult.[...] The poet must become more and more comprehensive, more allusive, more indirect, in order to force, to dislocate if necessary, language into his meaning. $" 52$

Now that the spiral of Russian history has completed one more revolution, the time may be ripe for a return to a form of philosophical or religious poetry, profound in thought and complex in expression - a tradition revived by Ivanov at the turn of the century, but subsequently broken off inside Russia by the course of postrevolutionary history. Khodasevich's perceptive comment, made from the standpoint of emigration in 1936, remains generally valid today - if Ivanov's poetry at times appears archaic, it is not because his thoughts have become antiquated and lost their relevance, but because modern Russian poetry has sadly lost touch with the tradition of a poetry of thought inspired by Baratynskii. ${ }^{53}$ In 1922 Mirsky made an appeal which went largely unheeded at the time but may now meet with a response: "Poeziia [Ivanova] nuzhna vsem, i, esli $k$ nei ne idut ili ee ne ponimaiut, tem khuzhe dlia neponimaiushchikh i ne idushchikh."54

School of Slavonic and East European Studies, University of London, 1993.

1. Osip Mandel'shtam, Letter of 13/26 August 1909 to Viacheslav Ivanov, in his Sobranie sochinenii $v$ trekh tomakh, edited by G.P. Struve and B.A. Filippov, 2nd ed, (New York, 1971), 2: 486.

2. From the essay "Buria $i$ natisk," in ibid. : 343.

3. The articles which appeared on Ivanov in the West during the years between his emigration and his death in 1949 almost all concentrate on his thought and role as a religious thinker. Discussion of his poetry tends to be in the light of these issues - the poetry is used to illustrate the ideas, rather than the other way round. When Ivanov scholarship began to pick up again in the Soviet Union and in the West in the late 1960's, interest was mainly focused on his role in literary and cultural history, either through minute reconstruction of archival materials of a literary-biographical nature, or through a more general discussion of his ideas and symbolist aesthetics. See the present author's forthcoming annotated bibliography of critical literature about Ivanov, Viacheslav Ivanov: A reference guide to literature (New York: G.K. Hall). The author would like to thank the British Academy and the Leverhulme Trust whose generous support of this project has facilitated work on this essay.

4. See De vulgari eloquentia, particularly Book II, iv. Selected parts of Dante's treatise began to appear in Russian translation from 1863; the first full translation (by V.B. Shklovskii) was published in 1922. See V.T. Danchenko, Dante Alig'eri: Bibliograficheskii ukazatel' russkikh perevodov $i$ kriticheskoi literatury na russkom iazyke. 1762-1972 (Moscow, 1973): 46.

5. For a brief but interesting discussion of Ivanov's links with Hölderlin in relation to their common spiritual preoccupations and elevated style in poetry, see Aleksis Rannit, "Hölderlin and the twentieth century: Is elevated style in poetry possible today?" in Emery E. George, ed., Friedrich Hölderlin: An early modern (Ann Arbor, The University of Michigan Press, 1972) : 115-116.

6. Two reasons for this may be suggested. English metaphysical poetry was not well known at the turn of the century in Russia (Marvell's visit to Russia as part of a British delegation, in the course of which the tsar presented him with two live bears and the head of a sturgeon, does not appear to have had much impact on literary circles; see Sarah Pratt, Russian metaphysical Romanticism: The poetry of Tiutchev and Boratynskii (Stanford, 1984): 220). Furthermore, the English metaphysical poets were more intellectual than philosophical, and less inclined towards mystical speculation than the other writers in whom Ivanov found inspiration.

7. In his "Avtobiograficheskoe pis'mo"(1917) Ivanov wrote: "Mat' vospityvala vo mne poeta, pokazyvala portrety Pushkina, gadala obo mne po Psaltyriu $i$ tolkovala mne slova o tom, chto 
psalmopevets byl iuneishim sredi brat'ev, $i$ chto ruki ego nastroili psaltir'."(Viacheslav Ivanov, Sobranie sochinenii (hereafter $S S$ ), ed. by D.V. Ivanov and O. Deschartes (Brussels, 1971-) II : 11). In stanza XLVI of Mladenchestvo he evokes the same memory, linked by his mother to his future poetic vocation - "Dar pesen veshchie listy/ Tebe prorochat'..." (SS, I : 253). The text which served as the source of his mother's prophecy was Psalm 151, lines 1-2 (not part of the original Hebrew Psalter, but a later addition from the Septuagint).

At the end of his life, Ivanov returned to the Book of Psalms once more and prepared a new edition using parallel translations from Greek into Church Slavonic and from Hebrew into Russian. In his introduction, he wrote about the Russian love of the Book of Psalms, used as a first text for learning how to read and write (Psaltir': Na slavianskom i russkom iazykakh (Rome, 1950) : xiii).

8. See, for example, Ivanov's essay of 1918, "Nash iazyk" in which he argued for the retention of archaic and difficult Church Slavonic elements of the Russian language and orthography, because he regarded Church Slavonic as the channel through which the Russian language had received the spiritual imprint of the "divine Greek language" (SS, IV : 676).

The impact which these views had on Ivanov's translations of various poets, from Dante to Novalis and Baudelaire has been documented in recent years. See the chapter "Ivanov's translations of Dante" in Pamela Davidson, The poetic imagination of Vyacheslav Ivanov: A Russian Symbolist's perception of Dante (Cambridge, 1989): 229-273; the chapter "Ivanov as translator of Novalis," in Michael Alex Wachtel, "Goethe and Novalis in the life and work of Vyacheslav Ivanov," Ph.D. dissertation (Harvard University, 1990) : 154-240; and the analysis of Ivanov's translations of Baudelaire in Adrian J. Wanner, "Metamorphoses of modemity: Russian readings of Baudelaire," Ph.D. dissertation (Columbia University, 1992) : 175-183, 211-213.

9. In his preface, "O pol'ze knig tserkovnykh v rossiiskom iazyke," Lomonosov recognized that literary Russian was a hybrid of Slavonic and the Russian vernacular and defined the high style of literary discourse in terms of its pronounced use of Church Slavonic words. Various early critics related Ivanov's use of Church Slavonic archaisms to Lomonosov's treatise; I. Dzhonson, for example, refers to Ivanov as a disciple of Lomonosov in this respect in the introduction to his review of Prozrachnost', Pravda: Ezhemesiachnyi zhurnal iskusstva, literatury, obshchestvennoi zhizni, 5 (May) (1905): 171-174.

10. For a discussion of the place of these two poets in the tradition of Russian metaphysical poetry, see S.Pratt, op. cit. : 9-15. For a more general survey of the fate of intellectual or philosophical poetry in the Russian tradition, see the essay "Poeziia mysli," in Lidiia Ginzburg, O lirike, 2nd ed. (Leningrad, 1974) : 51-126. There is also a useful anthology (including five poems by Ivanov), Mysl', vooruzhennaia rifmami: Poeticheskaia antologiia po istorii russkogo stikha, compiled, edited and annotated by V.E. Kholshevnikov, 2nd ed., revised and enlarged (Leningrad, 1987).

11. "Viacheslav Ivanov khotel kak by pereigrat' istoricheskuiu pobedu 'Arzamasa' nad slavianshchinoi 'Besedy liubitelei russkogo slova', cherez golovu Pushkina vernut'sia $k$ dopushkinskim istokam russkoi poezii.[...] Sviaz' Ivanova s zatrudnennymi khodami stikha Derzhavina, s temnymi glubinami filosofskoi liriki Tiutcheva bolee neposredstvennaia i krovnaia - pushkinskaia iasnost' simvolistu chuzhda."(from the introductory essay by S. Averintsev, in Viacheslav Ivanov, Stikhotvoreniia i poemy, ed. by R.E. Pomirchii (Leningrad, 1976): 35-36).

In later years, when asked by $\mathrm{Al}^{\prime}$ tman to comment on the view that his verse was difficult to read, compared with Pushkin's, Ivanov characteristically attempted to demonstrate that Pushkin's verse could also be obscure. See M.S. Al'tman, "Iz besed s poetom Viacheslavom Ivanovichem Ivanovym (Baku, 1921 g.),"Uchenye zapiski Tartuskogo gosudarstvennogo universiteta, 209, Trudy po russkoi i slavianskoi filologii. XI. Literaturovedenie (Tartu, 1968): 309.

Interesting comments on Ivanov's difficulty can be found in the article by Boris Filippov, "Viacheslav Ivanov," Grani, 89-90 (1973): 204-228. Filippov refers to Ivanov as "odin iz sanıkh neobkhodimykh nashim dniam bol'shikh poetov-liubomudrov" (ibid.: 212) [P.D. emphasis]. He derives Ivanov's difficulty from two sources; his wish to create an archaic style of Russian, rich in Church Slavonicisms, and his attempt to bring the language of poetry closer to that of prose. In this respect he characterizes Ivanov's language as a combination of Derzhavin and Pushkin (ibid.: 222).

The rich area of Ivanov's links with eighteenth-century poetry would merit further investigation. So far the only treatment of the subject has been the stimulating essay, including an interesting discussion of the issue of difficulty, by Ilya Serman, "Vyacheslav Ivanov and Russian poetry of the eighteenth century," in Robert Louis Jackson and Lowry Nelson, eds, Kyacheslav Ivanov: Poet, critic and philosopher (New Haven, 1986): 190-208.

At the III International Symposium on Ivanov held in Rome in 1983, Serman also gave a paper on Ivanov's links with Tiutchev, a key figure in the poet's "ottalkivanie ot Pushkina" (S. Averintsev, in op. cit.: 35). A few pages are devoted to this topic in the article by N.K. Gudzii, "Tiutchev v poeticheskoi 
kul'ture russkogo simvolizma," Akademiia nauk SSSR; Izvestiia po russkomu iazyku i slovesnosti (Leningrad), 3, 2 (1930) : 465-549. A chapter on Ivanov is included in the thesis by Giovanna Calebich Creazza, "F.I. Tjutcev e i simbolisti" (Università degli Studi di Venezia, 1985), a copy of which is held in the poet's archive in Rome.

12. The revival of interest in Tiutchev, initiated in the 1890's by Merezhkovskii, Solov'ev and Briusov, was still gathering momentum. Solov'ev had a well-established reputation as a philosopher and prose writer, but his poetry did not become well known until the early 1900 's.

13. See for example the following comments in a contemporary review of Kormchie zvezdy: "Trudno sebe dazhe predstavit', chtoby kto-libo inoi, krome arkhivnogo filologa, mog sdelat' popytku voskresit' $v$ sovremennoi literature $i$ poezii drevnii klassitsizm, drevnii 'shtil' $i$ iavit'sia sovremennym dvoinikom samogo gospodina Tred'iakovskogo./.../Kak poet, g. Ivanov opozdal na tselye stoletiia.[...] A seichas g. Ivanovu, Tred'iakovskomu nashikh dnei, my s grust'iu mozhem skazat' 'zapozdali'."(Nik. Asheshov, Review of Kormchie zvezdy: Kniga liriki, Obrazovanie, 12 (Dec.), (1903), otd. III: 118-119).

14. A. Nalimov's review of Kormchie zvezdy is typical in this respect. It opens with the words: "Poeziia V. Ivanova prezhde vsego kakaia-to uchenaia. Sam avtor schel nuzhnym snabdit' svoiu knigu primechaniiami" and concludes: "Trudy ego my zamechaem; no khudozhestvennogo gipnoza ne oshchushchaem," pointing out, as if it were a fault, that the author's true penchant lies towards philosophy (Literaturnyi vestnik, 5, 4 (1903): 496-497).

15. See the two parodies in Aleksandr Izmailov, Krivoe zerkalo. Parodii i sharzhi (SPb, 1910): 24-25. The second one carries an epigraph from a poem included in Eros and subsequently in Cor ardens ("Tseliashchaia"), and links Ivanov's name to Trediakovkii, Derzhavin and Kiukhel'beker; it includes the lines "Dokol'v piitakh zhiv Ivanov Viacheslav, - / Vzbodrias', volkhvuet Tred'iakovskii". Both these parodies date from 1907 and are reprinted with three other parodies of Ivanov from 1907, 1908 and 1915 in A.A. Morozov, ed., Russkaia stikhotvornaia parodiia: XVIII - nachala XX v. (Leningrad: Biblioteka poeta. Bol'shaia seriia, 1960): 639-642 (the last of these, also by lzmailov, carries another epigraph from Cor ardens, from the third sonnet of the cycle "Spor" in "Liubov' i smert").

16. For references to Briusov's reviews of Ivanov's early collections, see note 17 below. In his first review of Prozrachnost', Blok underlined the scholarly and philosophical nature of Ivanov's verse ("poeziia Viach. Ivanova mozhet byt' nazvana 'uchenoi' $i$ 'filosofskoi' poeziei") and pointed out that it is intended for readers whose breadth of experience is matched by depth of thought; in defining Ivanov's ideal readership as "poroda liudei, kotoroi suzhdeno vse izviliny svoei zhizni obagriat' krov'iu mysli" he was deliberately emphasizing the living aspect of thought and its intimate connection with experience (Aleksandr Blok, Review of Prozrachnost': Vtoraia kniga liriki, Novyi put', 6 (June), (1904): 204-206).

In his second article he defended the poet's difficulty from a different angle: "Nevniatnyi iazyk, temnaia chastnost' simvola - muchitel'no neobkhodimaia stupen' $k$ solnechnoi muzyke, $k$ svetlomu vseobshchemu mifu"; see Aleksandr Blok, "Tvorchestvo Viacheslava Ivanova," Voprosy zhizhi, 4-5 (Apr.May) (1905): 198.

17. Briusov reviewed almost all of Ivanov's collections of poetry (apart from Nezhnaia taina); his example is particularly interesting as it enables us to follow the development of his response. For a useful annotated edition of the original texts of his reviews of Kormchie zvezdy, Prozrachnost', Eros, Cor Ardens (both parts), Mladenchestvo and Prometei, see Valerii Briusov, Sredi stikhov. 1894-1924: Manifesty, stat'i, retsenzii, compiled by N.V. Bogomolov and N.V. Kotrelev, introduction and notes by N.A. Bogomolov (Moscow, 1990): 74-75, 107-108, 224-228, 341-346, 362-376, 531, 547-549.

18. In his 1903 review of Kormchie zvezdy he describes Ivanov as a "nastoiashchii khudozhnik, ponimaiushchii sovremennye zadachi stikha, rabotaiushchii nad nimi" and takes pains to underline his relevance to contemporary searchings: "Viacheslav Ivanov istinno sovremennyi chelovek, prichastnyi vsem nashim iskaniiam, nedoumeniiam, trevogam." (Valerii Briusov, Review of Kormchie zvezdy, Novyi put', 3 (March), (1903) : 212-214).

In his 1904 review of Prozrachnost', he was even more positive; Ivanov's verse was found to reflect the accumulated wisdom of centuries ("umudrennost' tysiacheletii"), and his return to earlier models for form and language is described as enriching and innovative. His poetry requires only a certain "vdumchivaia ser'eznost" from his reader; if the reader bores into the hard rock of Ivanov's verse, he will discover the silver springs of true poetry. Here for the first time the innovative nature of Ivanov's poetry in relation to the demands it places upon its reader was spelled out clearly in a positive light (Valerii Briusov, Review of Andrei Belyi, Zoloto v lazuri and of Viacheslav Ivanov, Prozrachnost', Vesy, 4 (1904)).

19. In this context it is interesting to note that in 1911, when Briusov was revising his earlier reviews of Ivanov's previous collections for publication in Dalekie $i$ blizkie, he added several substantial sections, most of which were specifically in defense of various aspects of Ivanov's difficulty as a poet. 
20. Valerii Briusov, "Novye sborniki stikhov," Russkaia mysl', 7 (July), (1911) : 20-24; id., "Segodniashnii den' russkoi poezii: (Iz sbornikov stikhov 1911-1912 g.)," ibid., 7 (1912), otd. III: 17-28 (pp. 17-18, 20, 28 deal with Ivanov).

21. For a review of this debate, see Joan Delaney Grossman, "Briusov's defense of poetry and the crisis of symbolism," in J. Douglas Clayton, ed., Issues in Russian literature before 1917, Selected Papers of the Third World Congress for Soviet and East European Studies (Columbus, Ohio, 1989): 196-204.

22. Briusov concludes his review article with the following words: "Itogi? Iz rassmotrennykh nami 50 s lishkom sbornikov deistvitel'no tsennoi nam kazhetsia tol'ko - novaia kniga Viach. Ivanova." Among the other poets whose recent works were reviewed in the article were Blok, Bal'mont, Baltrushaitis, Gumilev, Severianin, Georgii Ivanov, Akhmatova and Tsvetaeva.

23. Not surprisingly, Ivanov was proud of the first review and even more so of the second. See his letters to Briusov of 6 March 1912 and 22/9 January 1913 in Literaturnoe nasledstvo, 85: Valerii Briusov (Moscow, 1976): 535-536.

24. M. Kuzmin, "Cor Ardens Viacheslava Ivanova," Trudy $i$ dni, 1 (Jan.-Feb.) (1912): 49-51. Kuzmin's review appeared relatively late, some months after Briusov's and Chulkov's reviews of the first part of Cor Ardens. The history of its publication in incomplete form and Kuzmin's subsequent attempt to dissociate himself from the journal are mentioned by Kuzmin in his "Pis'mo v redaktsiiu," published in Apollon, 5 (1912): 56-57, and discussed at further length by John Malmstad in his "Mixail Kuzmin: A chronicle of his life and times," in M.A. Kuzmin, Sobranie stikhov III, compiled and edited by John E. Malmstad and Vladimir Markov (Munich, 1977): 173-175. The full text of the original review with an accompanying introduction and notes is currently being prepared by N.A. Bogomolov for publication in an anthology of Kuznin's critical prose to appear in Berkeley under the editorship of George Cheron.

25. See John A. Barnstead, "Mikhail Kuzmin's 'On beautiful clarity' and Viacheslav Ivanov: A reconsideration," Canadian Slavonic Papers, 24, 1 (March) (1982): 1-10.

26. In this he echoes Briusov's comments (in his earlier review of Prozrachnost') on the particular challenges and rewards presented by Ivanov's verse to the reader.

27. [P.D. empliasis]. Kuzmin's view of Ivanov as a poet whose meaning is fundamentally "simple" even if the manner of its expression is complex has been restated for the modern reader by Markov, who finds that Ivanov traces a path through complexity towards simplicity, illustrating his own maxim : " $K$ prostote. [...] put' idet cherez slozhnost" (Vladimir Markov, "O pervom tome Sobraniia sochinenii Viacheslava Ivanova: (Okonchanie)," Russkaia mysl', 2887 (23 March 1972) : 7), and by S.Averintsev, who writes that "the poetry of Ivanov, which has so often been found to be obscure, in fact turns out to be unusually clear - a poetry of precise contour and firm, slowly unfolding significance." (Sergey Averintsev, "The poetry of Vyacheslav Ivanov," in R.L. Jackson and L. Nelson, eds, op. cit. : 41).

28. Georgii Chulkov, "Poet-kormshchik," Apollon, 10(1911): 62-64. A slightly adapted version of the review was reprinted in his Nashi sputniki: 1912-1922 (Moscow, 1922): 65-70, and a considerably abridged version in his book of memoirs, Gody stranstvii: Iz knigi vospominanii (Moscow, 1930): 242-243.

29. San Clemente, located near the Coliseum, is one of most important ancient churches of Rome. Excavations begun in 1858 revealed the existence of an earlier, much larger church at a lower level, containing mural paintings depicting the legends of Sts. Cyril and Methodius. This church was in turn built over a chapel of Mithras, the Persian and Indian sun-god whose cult was taken over by Imperial Rome and showed striking similarities with Christianity.

30. Briusov made the same point about Ivanov's preoccupation with eternal issues, but used it to suggest the opposite, that Ivanov was not a poet for the present day.

31. Chulkov evidently suggested to Gumilev that he should contribute a second review of the same book to Apollon. See Gumilev's reply, posted on 15 September 1911, in which he accepted Chulkov's proposal, adding :"Mne eto budet ochen' priiatno, tak kak ia iskrenne ne veriu v svoiu sposobnost' vsestoronne osvetit' takuiu znachitel'nuiu knigu." (Nikolai Gumilev, Neizdannoe i nesobrannoe, compiled, edited and with commentaries by Michael Basker and Sheelagh Duffin Graham (Paris, 1986): 127).

32. Apollon, 7 (1911): 75-76; 6 (1912): 52-53. For a fuller analysis of these reviews, see the present author's essay, "Gumilev's reviews of Viacheslav Ivanov's Cor Ardens: Criticism as a tool in the polemics of literary succession," in Faith Wigzell, ed., Russian writers on Russian writers, with an introduction by Robin Aizlewood and Faith Wigzell (Providence, Rhode Island and Oxford: Berg, forthcoming, 1994).

33. Ivanov's lines “- Chto tvoi znak? - 'Prozren'e glaza,/ Dal'nost' slukha, okrylen'e nog'." [P.D. emphasis], from the final verse of "Prishlets" (in Prozrachnost', reprinted in SS, I : 753) were appended by Gumilev to the "Zhemchug rozovyi" section of his third collection, Zhemchuga (1910).

34. Gumilev is reversing the archetypal progression from darkness to light, from Dante's cave to the stars, posited by Ivanov and Blok as the future path to be travelled by symbolist art. See Blok's "Tvorchestvo Viacheslava Ivanova" and note 16 above. 
35. "Viacheslav Ivanov poet - molodoi, t.e. daleko eshche ne proshedshii vsekh putei svoego razvitiia, no puti ego perestali byt' pokazatel'nymi dlia russkoi poezii, oni nuzhny $i$ radostny tol'ko dlia samogo poeta.[...]Mezhdu Viacheslavom Ivanovym i akmeizmom propast', kotoruiu ne zapolnit' nikakomu talantu." (Apollon, 3 (March), (1913): 74-75). In his other review of Nezhnaia taina, published in Giperborei, 4 (Jan.) (1913): 27, Gumilev wrote : "kniga napisana neobychnym dlia V. Ivanova prostym i prekrasnym iazykom" but refrained from any type of negative comment [P.D. emphasis].

36. Ibid., 1 (Oct.) (1912): 28-29. Only these two reviews were written by Gorodetskii; the others in the issue were written by Gumilev (for the attribution of authorship see Roman Timenchik, "Zametki na poliakh: No. 1," ibid., 1 (Oct.) (1912) (facsimile reprint, Leningrad, 1990): 33).

37. In his opening editorial note, Gorodetskii includes Ivanov's name in a list of great poets of the past running from Lomonosov to Blok who represent the pride of Russian poetry, and then looks towards the future, adding “...russkaia poeziia predchuvstvuet novye zavoevaniia."

38. [P.D. emphasis]. Quoted by R.Timenchik, art. cit.

39. The essay "Blizhaishaia zadacha russkoi literatury" was first published in 1909 in Zolotoe runo and is reprinted with cuts in Sergei Gorodetskii, Zhizn' neukrotimaia: Stat'i. Ocherki. Vospominaniia, ed. by V.P. Enisherlov (Moscow, 1984): 92-110 (comments on Ivanov's use of imagery and language, compared to Remizov's, on pp. 98-99).

40. Vladislav Khodasevich, "Russkaia poeziia: obzor," in Al'tsiona: Kniga pervaia (Moscow, 1914): 196-198.

41. San Marco in its present form was rebuilt in the eleventh century as a private chapel for the Doges. Its interior marble and mosaic decorations were added over the next six centuries, and its treasury contains a unique collection of plate and jewellery, mostly of Byzantine origin.

42. Ivanov's poem speaks of the whole world bringing its riches to rest in San Marco for the Doges. It compares the church to a stooped figure in robes of heavy brocade (curiously evocative of Ivanov himself), and refers to it as a "darokhranitel'nyi kovchezhets Bozhii." The poem was included in the fourth book of Cor Ardens, "Rosarium", most of which was written in 1910. Ivanov and Vera passed through Venice at the end of the summer of 1910 after their earlier reunion in Rome (for the text of the poem and notes, see $S S$, II: $498,810-812$ ).

43. See, for example, the anonymous review of "Cor Ardens: Chast' vtoraia," in Ezhemesiachnye literaturnye i populiarno-nauchnye prilozheniia $k$ zhurnalu Niva na $1912 \mathrm{~g}$. (SPb), 3: 295 . The author writes of Ivanov's "svoeobraznyi, starinnyi, nemnogo tiazhelovatyi stil" and concludes: "Mnogoe v nem bleshchet nastoiashchei poeziei, no koe $v$ chem chuvstvuetsia 'zapakh lampady' - nechto sukhoenauchnoe, govoriashchee o redkoi obrazovannosti $i$ uchenosti avtora, no ne o neposredstvennom vdokhnovenii."

44. The difference of opinion followed the line of division between the generations. Gorodetskii, Gumilev and Khodasevich were between eleven and fourteen years younger than Briusov or Kuzmin and represented a new generation of poets; this inevitably meant that their view of the future direction of Russian poetry was intimately bound up with their own problems of "self-definition" and orientation.

45. After attending Ivanov's lectures for young poets on the theory of verse (held at the Poetic Academy in the tower in 1909) Gumilev wrote to Briusov: "I mne kazhetsia, chto tol'ko teper' ia nachinaiu ponimat', chto takoe stikh." (undated letter in N.S. Gumilev, Neizdannye stikhi i pis'ma (Paris, 1980): 61). As early as 1906, Gumilev was studying Ivanov's Prozrachnost' in order to master new techniques of versification, following the advice of Briusov. See his letter of 30 October 1906 to Briusov in N.Gumilev, Neizdannoe $i$ nesobrannoe, op. cit.: 96-97. On echoes of Ivanov in other poets such as Voloshin, Khlebnikov or Pasternak, see V. Markov, art. cit.: 7.

46. Briusov was particularly sensitive in his 1903 review of Kormchie zvezdy to Ivanov's tremendous contribution in this area; when he revised this review in 1911 for inclusion in Dalekie i blizkie, he greatly expanded the introductory section on the Russian tradition of versification in order to highlight Ivanov's achievements in this area.

47. For the source of Mandel'shtam's comment, see note 1 above. A recent contribution to the subject of Ivanov's "negative" influence on Mandel'shtam is given by Diana Myers in her essay "'Hellenism' and 'barbarism' in Mandel'shtam," in Arnold McMillin, ed., Symbolism and after: Essays on Russian poetry in honour of Georgette Donchin (London, 1992): 85-101.

48. See the diary entry for 17 April 1912 in Aleksandr Blok, Sobranie sochinenii, ed.by V.N. Orlov (Moscow - Leningrad, 1963) VII: 140.

49. Tsvetaeva's three poems to Ivanov can be found in Marina Tsvetaeva, Sochineniia, ed. by Auna Saakiants (Moscow, 1988) I: 114-116. Another example of the indirect transmission of Ivanov's influence is provided by Pasternak; see the interesting comments on his refashioning of Ivanov's ideas on syınbolism in Lazar Fleishman, Boris Pasternak: The poet and his politics (Cambridge, Mass. - London, 1990): 49-52. 
50. [P.D. emphasis]. N.V. Nedobrovo, "Obshchestvo revnitelei khudozhestvennogo slova v Peterburge," Trudy i dni, 2 (March-Apr.), (1912): 27.

51. Sergei Gorodetskii, Zhizn' neukrotimaia, op. cit.: 210.

52. [P.D. emphasis]. T.S. Eliot, "The metaphysical poets," in Selected prose of T.S. Eliot, ed. with an introduction by Frank Kermode (London, 1975): 65.

53. Vladislav Khodasevich, "Knigi i liudi: Sovremennye zapiski, kn. 62-ia," Vozrozhdenie (Paris), 4058 (25 Dec.1936): 9. The first section of this article is devoted to an enthusiastic appraisal of Ivanov's "Roman sonnets," published in the journal issue under review. Earlier in the article Khodasevich applies Pushkin's comment on Baratynskii to the case of Ivanov in order to dispel the notion that intellectual content and emotional feeling are mutually exclusive in poetry ("Nikto bolee Boratynskogo ne vlozhil chuvstva v svoi mysli'. Eti Pushkinskie slova, mozhet byt', primenimy $k$ Viacheslavu Ivanovu eshche vernee, chem $k$ samomu Boratynskomu.")

54. D. Sviatopolk-Mirsky, "O sovremennom sostoianii russkoi poezii," Novyi zhurnal, 131 (1978): 98. 